YUNUS EMRE

VE DÜNYA DiLi

TÜRKÇE YILI
- .
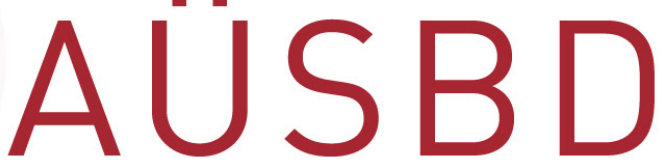

Anadolu Üniversitesi Sosyal Bilimler Dergisi

Anadolu University Journal of Social Sciences

\title{
Yunus Emre'nin Tarikat Sorunu ve Yaşadığı Dönemde Eskişehir Kent Merkezinde Bulunan Zaviyeler ${ }^{1} 23$
}

\author{
Selma MANAZ ${ }^{4}$
}

Başvuru Tarihi: 15.11.2021

Kabul Tarihi: 03.01 .2022

Makale Türü: Araştırma Makalesi

\section{Öz}

Yunus Emre'nin yaşadığı 13. ve 14. yüzyıllar, Anadolu Selçuklularının son dönemi, Beylikler ve Osmanlı Devleti’nin kuruluş yıllarını içermektedir. Anadolu bu yüzyıllarda Haçh seferleri, Moğol akınları ve Babailer isyanına maruz kalmıştır. Bu dönemde Anadolu'da kurularak gelişen tarikatlardan başka, Anadolu dişında oluşmuş çeşitli tarikatların temsilcileri de Anadolu'ya gelerek kendi tarikatlarını yaymaya başlamışlardır. Böylece Anadolu'da birbirinden farklı tarikatlara sahip zaviyelerin sayısı da artmıştır. Bu çalışmada, öncelikle Yunus Emre'nin mensup olduğu tarikat tespit edilerek, Eskişehir kent merkezinde kurulan tarikatlar ile ortak özelliklerinin tespit edilmesi amaçlanmıştır. Bu nedenle özellikle Yunus Emre’nin eğitimi, eserleri ve adına kurulan zaviye üzerinden sonuca ulaşılmaya çalışılmıştır. Ancak Yunus Emre'nin aldığı eğitim, şiirlerinde oniki imamdan bahsetmemesi ve değişen zamanla birlikte adına yaptırılan zaviyenin zaviyedarlar ile tarikatlarının değişmesi Yunus Emre'nin mensup olduğu tarikatın belirlenmesini zorlaştırmıştır. Dolayısılla mensup olduğu tarikattan ziyade mensup olamayacağı tarikatların belirlenmesi mümkün olmuştur. Eskişehir kent merkezinde Yunus Emre'nin yaşadığı dönemdeki gibi birbirinden farklı tarikatlarda zaviyeler kurulmuştur. Ancak bu tarikatlar ile Yunus Emre'nin mensup olabileceği düşünülen tarikatlar arasında bir bă̆ kurulamamıştır. Günümüzde bir iki sokak arayla kurulan bu tarikat zaviyelerinin yerlerinde türbeleri bulunmaktadır.

Anahtar Kelimeler: Yunus Emre Zaviyesi, Zaviye, Abd Allah el Bedevi, Sühreverdi, Nusrettin, Ahi Mahmud

Atıf: Manaz, S. (2022). Yunus Emre’nin tarikat sorunu ve yaşadığı dönemde Eskişehir kent merkezinde bulunan zaviyeler. Anadolu Üniversitesi Sosyal Bilimler Dergisi, 22(Özel Sayı), 119-138.

\footnotetext{
${ }^{1}$ Bu çalışma etik kurul izin belgesi gerektirmemektedir.

${ }^{2}$ Bu çalışma, "Bizans Dönemi Dorylaionu ile Anadolu Selçuklu Şehri Sultan Eyüğü/ Sultan Öyügü̈'nün (Eskişehir) Fiziki Yapıları" başlıklı Anadolu Üniversitesi Bilimsel Araştırma Projeleri Komisyonunca kabul edilen ve 1503E100 nolu proje kapsamında desteklenen doktora tez çalışmasından türetilmiştir.

3 “Yunus Emre’nin Tarikat Sorunu ve Yaşadığı Dönemde Eskişehir Kent Merkezinde Bulunan Zaviyeler" başlıklı makalemde danışman hocam Prof. Dr. Canan PARLA'nın isminin yazar olarak bulunmasından feragat ettiğini bildiririm

${ }^{4}$ Anadolu Üniversitesi Edebiyat Fakültesi Sanat Tarihi Bölümü, smanaz@anadolu.edu.tr, ORCID: 0000-0003-3767-1249
} 


\title{
The Problem of Obscurity Over Yunus Emre's Religious Sect Membership and Zawiyahs in Eskişehir City Center In His Lifetime
}

\author{
Selma MANAZ ${ }^{5}$
}

Submitted by: 15.11 .2021

Accepted by: 03.01 .2022

Article Type: Research Article

\begin{abstract}
The 13th and 14th centuries, in which Yunus Emre lived, cover a time span that includes last period of the Anatolian Seljuks, initial years of the Anatolian Principalities and the foundation Ottoman State. Anatolia was exposed to the Crusades, Mongol raids and Babai rebellion in those centuries. In this period of time, not only the religious sects with Anatolian origin established and developed in Anatolia but also religious sects originated elsewhere came into Anatolia and began to spread their ideas and religious order in Anatolian soil. Therefore, the number of religious sects and zawiyas increased in Anatolia during this period. The aim of this study is to determine the religious sect that Yunus Emre belonged to and to find out the common features between the religious sect he belonged to and other sects which were established in the city center of Eskisehir. For reaching this aim, the study especially focuses on Yunus Emre's education, his works and the Zawiyah established in his name However, Yunus Emre's education, no mention of 12 Imams in his poems and the change of religious sect with the members of the Zawiyah established in his name in time, made it difficult to determine the religious sect he belonged to. Therefore, it sounds much more plausable to determine the sects he could not be a member of, rather than the sect he belonged to. In Yunus Emre's lifetime, many zawiyas were established in the city center of Eskişehir. Those zawiyas have different sect structures and orders like many others established in the time period Yunus Emre lived. Those zawiyas, were established one or two streets apart in the same neighborhood. Today, there are tombs in the places of those zawiyas.
\end{abstract}

Keywords: Yunus Emre Zawiyah, Zawiyah, Abd Allah el Bedevi, Sühreverdi, Nusrettin, Ahi Mahmud

\footnotetext{
${ }^{5}$ Anadolu University Faculty of Humanities Department of Art History, smanaz@anadolu.edu.tr, ORCID: 0000-0003-3767-1249
} 


\section{Giriş}

Yunus Emre'nin yaşadığı 13. ve 14. yüzyıllarda Eskişehir kent merkezinde bulunan zaviyelerden Şeyh Abdullah Bedevi’ye ait olan zaviyenin, 1272 tarihli Caca oğlu vakfiyesinde tamir edildiği belirtildiği için Selçuklu döneminde kesin olarak var olduğu bilinen tek yapıdır (Caca Oğlu Nur El-din, çev. 1989, s.11, 97, 128, 129, 202). Diğer zaviyeler ise yazılı kaynaklarında vakf-ı kadim olarak belirtildiği için Selçuklu dönemine tarihlenmektedir.

Şimdiye kadar Yunus Emre ile ilgili yapılan çalışmalarda onun eğitimi ve şiirleri üzerinden mensup olabileceği tarikatı belirlenmeye çalışılmıştır. Ayrıca 15. yüzyılda onun adına kurulan zaviyenin zaviyedarları dikkate alınarak, Hacı Bayram-1 Veli'nin müridiyken onun emriyle 15. yüzyılda Hama'ya gidip Abdülkadir-i Geylani'nin soyundan Hüseyin el-Hamevl'den hilafet alan Eşrefoğlu Rumi'nin Anadolu'ya getirdiği Kadiriyye tarikatına mensup olduğu düşünülmüştür (Azamat, 2001, s. 132-133). Kadiriye tarikatı Anadolu ve Anadolu dışında oldukça hızlı yayılan bir tarikat olmasına karşın Yunus Emre'nin yaşadığı dönemden sonra Anadolu' da yaygınlaşmıştır. Yunus Emre'nin zaviyesine Kadiriye tarikatına mensup zaviyedarlar atandıktan sonra geç dönemde atanan zaviyedarının Ahi bağlantılı (Topal, 2010, s.73) olması zaviyedar atamalarında yaşanan dönemde hangi tarikat etkili ise o tarikatın Yunus Emre'yi benimsediğini düşündürmektedir. Çünkü Yunus Emre gerek Anadolu'da gelişen gerek Anadolu dışından getirilip yaygınlaştırılan tarikatların yoğun olduğu bir dönemde yaşamıştır. Bunun en iyi kanıtını da Eskişehir'de Selçuklu döneminde Bedeviyye tarikatı, Sühreverdiyye tarikatı (Manaz, 2019, s.128), Şeyh Edebali-Ahi Ede'nin mensup olabileceği düşünülen Vefaiyye tarikatı (Erdoğan, 2015, s. 314-327) ve Abbasi halifesi Nasır li-Dinillah'ın, Anadolu Selçuklu Sultanı I. Keykavus'u 1216 tarihinde fütüvvet teşkilatına almasından sonra Anadolu'ya geldiği kabul edilen ahilik teşkilatından (Ocak, 1978, s. 259) Ahi Mahmud Zaviyesi’nin yer almasıdır. Bu tarikatlar Eskişehir kent merkezinde, Selçuklu ve Osmanlı dönemi yerleşim yeri olan Odunpazarı semtinde yaklaşık 2 km'lik alan içinde birbirinden farklı tarikatlara mensup olan zaviyelerini kurmuşlardır.

Yunus Emre'nin tarikatının tespit edilerek Eskişehir kent merkezindeki Odunpazarı semtinde kurulan tarikatlar arasında ortak özelliklerin arandığı bu çalışma Yunus Emre'nin tarikatının belirlenmesinin neden zor olduğunu ve Yunus Emre'nin yaşadığı dönemdeki zengin tarikat çeşitliliğinin Eskişehir kent merkezinde de yaşandığını göstermesi açısından önemlidir.

Yunus Emre'nin yaşadığı dönem.

Yunus Emre'nin H.638 (M.1240-1241) ve H.720 (M.1320-1321) yılları arasında yaşadığı görüşü genel olarak kabul gören tarihlerdir. Yunus Emre’ye ait olduğu ileri sürülen birçok yerde makam türbesi bulunmaktadır (Yetim, 2005, s.173).

Anadolu'da Yunus Emre'nin mezarının bulunduğu belirtilen yerler şunlardır: Eskişehir Sarıköy (günümüz Yunusemre Köyü), Karaman, Aksaray Ortaköy, Bursa, Manisa Kula Emresultan Köyü, Erzurum Dutçu (Düzcü) köyü, Isparta Keçiborlu, Afyon Sandıklı, Ankara Nallıhan Emremsultan Köyü, Ünye ve Sivas’tır (Tatc1, 2013, s.602).

Eskişehir Sarıköy'de bulunan Yunus Emre mezarı Ankara-Eskişehir demiryolu hattı inşaatı sırasında 6 Mayıs 1946 tarihinde açılarak (Şekil 1) cenazesi geçici mezara nakledildikten sonra (Şekil 2), 1970 yılında yapılan bugünkü yerine (Şekil 3) defnedilmiştir. Fuad Köprülü, Abdülbaki Gölpınarlı ve Faruk K. Timurtaş da Yunus Emre’nin mezarının burada yer aldığını kabul etmişlerdir (Tatcı, 2013, s.602). 


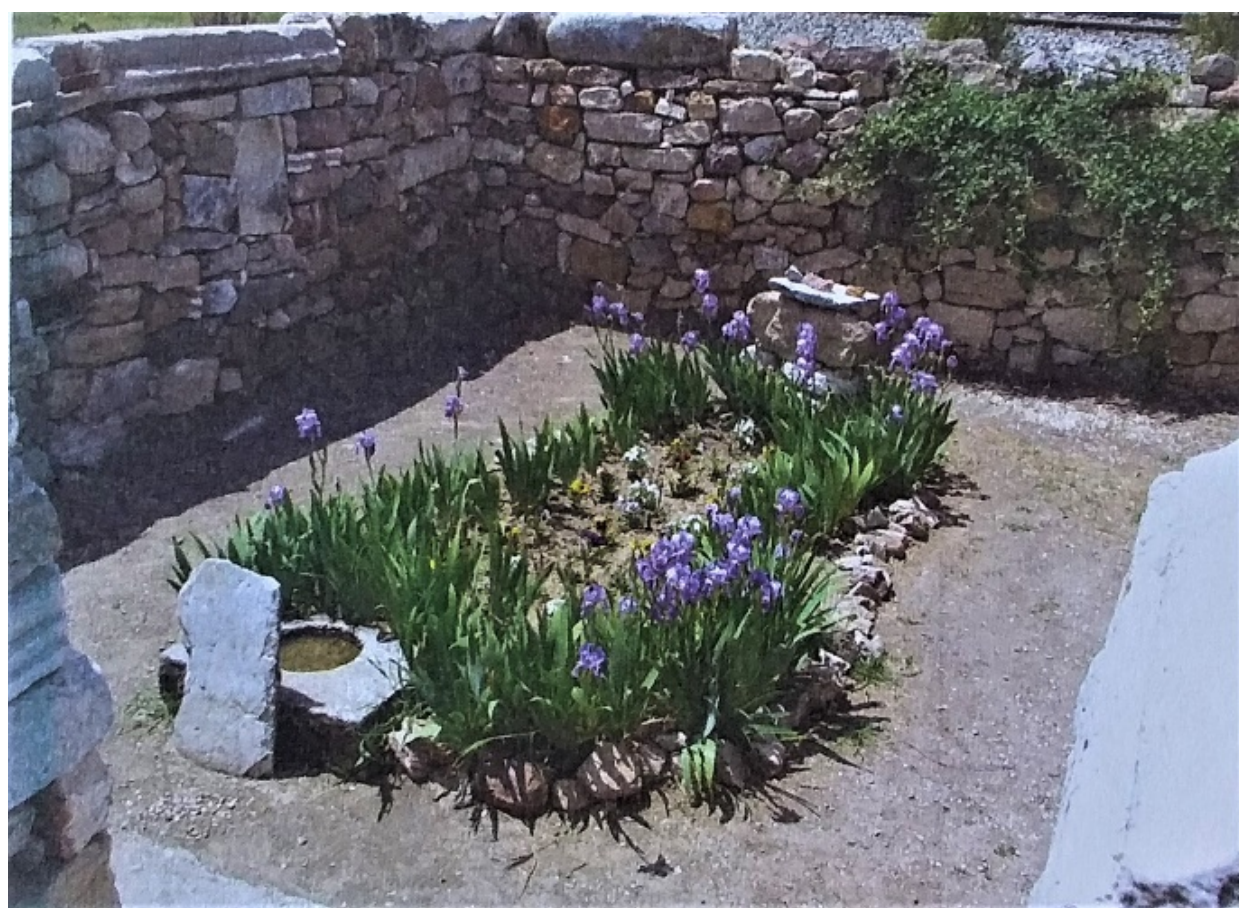

Şekil 1. Yunus Emre 1.Türbe (Altınsapan ve Parla, 2010)

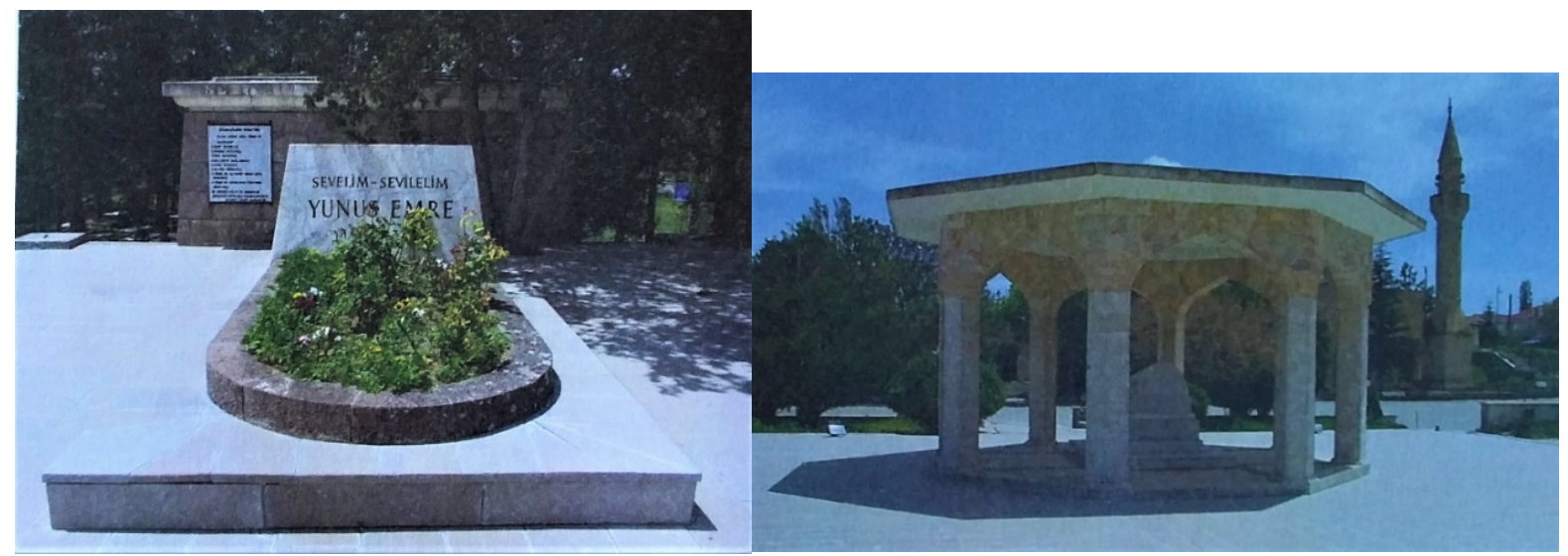

Şekil 2. Türbe (Altınsapan ve Parla, 2010)

Şekil 3. Türbe (Altınsapan ve Parla, 2010)

Yunus Emre'nin türbesi Kültür Bakanlığı ve Bayındırlık İskan Müdürlüğü tarafından Prof. Dr. Süheyl Ünver başkanlığındaki bir mimar grubu tarafından 1970 yılında inşa edilmiştir. Türbe sekizgen baldaken planlı, dışa taşkın çatılıdır (Altınsapan -Parla, 2010, s. 94). (Şekil 3).

Yunus Emre (1240-1321) Eskişehir'in Mihalıçcık ilçesine bağlı Sarıköy'de doğup gençliğini de burada geçirdikten sonra, Ankara Nallıhan'da Emrem Sultan Mahallesi'nde yaşayan Tapduk Emre'den eğitim alarak tekrar doğduğu Sarıköy’e dönmüştür. Yunus Emre bazen kendisi bazende şeyhi Tapduk Emre’yle birlikte Anadolu, Ortadoğu, Azerbaycan ve Rumeli'ye seyahatler yapmıştır (Tatc1, 2020, s.3).

Yunus Emre'nin yaşadığı 13. ve 14. yüzyıllar, Anadolu Selçuklularının son dönemi, beylikler ve Osmanlı Devleti'nin kuruluş yıllarını içermektedir. Bu dönemde Anadolu'da "Haçlı seferleri, Moğol saldırıları ve Babailer isyanı hakimdir (Özçelik, 2010, s. 10). 
Anadolu'ya yapılan göçler, Anadolu’nun hızla Türkleşmesini sağlarken 1240 tarihinde bir Türkmen hareketi olan Babai isyanının çımasına da sebep olmuştur. İsyanın bastırılmasından sonra Türkmenler büyük kitleler halinde Anadolu'nun kuzey, güney ve batıda yer alan uç bölgelerine yerleşmeye başlamıştır (Manaz, 2019, s.61).

1262 tarihinden sonra devlet yönetiminde Selçuklu Sultanlarının etkisi giderek azalırken, Moğol valilerinin etkisi altındaki devlet adamlarının nüfuzu artmıştır. Kırşehir valiliği Caca Oğlu Nur El-din’e verilmiştir. Moğolca Arapça 1272 tarihli Cacaoğlu vakfiyesine göre Caca oğlu Nureddin, Kırşehir valiliğine atandığı 1262 yılı öncesinde, Eskişehiri'de o dönemdeki adıyla Sultaneyüğü/Sultanöyüğü şehrinde valilik yapmıştır (Manaz, 2019, s.58). 1272 tarihli vakfiyeye göre Caca Oğlu Nur El-din valiliği süresi içerisinde Eskişehir'de birçok han, cami, Şeyh Abd Allah el Bedevi'ye Zaviyesi gibi yapıları tamir ettirmiş veya Odunpazarı yerleşiminde bulunan Alaadin Camii gibi bazı yapıları da inşaa ettirmiştir (Caca Oğlu Nur El-din, çev. 1989, s.11, 97, 128, 129, 202).

Yunus Emre'nin tarikatı.

Orta Asya'da Cengiz Han’ın (ö. 624/1227) ve Hülagü Han'ın (ö. 663/1265) liderliğindeki Moğol istilaları nedeniyle halk henüz istilaya uğramamış Anadolu gibi güvenli bölgelere doğru ilerlemişlerdir (Ürkmez, 2021, s.182). 13-14. yüzyıllarda Kazerûnilik, Evhadilik, Vefailik, Rifailik gibi, silsileleri Anadolu dışında oluşmuş tarikatların temsilcileri Anadolu’ya gelmişlerdir. Ayrıca 13. yüzyılda Şihabeddin-i Sühreverdi (ö. 632/1234), Muhyiddin İbnü’l-Arabi (ö. 638/1240), Mevlana Celaleddin-i Rumi (ö. 672/1273) gibi sufi şair ve müellifler de yetişmiştir (Ürkmez, 2021, s.181-182). Dönemin siyasi ve sosyal şartları değerlendirildiğinde bu göç dalgası, 13. yüzyılda gerek Anadolu'da gelişen gerek dış kaynaklı kurulan tarikatların çeşitliliğinin nedenini de göstermektedir. Örneğin Hacı Bektaş-1 Veli (ö. 669/1271?) Horasan'dan gelerek Sulucakarahöyük'e (bugünkü adıyla Hacıbektaş) yerleşmiştir. Ayrıca Baba İlyas (ö. 637/1240) gibi bazı sufiler öğretilerini yaymak için bir tarikat şeyhi halifesi olarak Anadolu’ya gelmiş veya gönderilmiştir (Ürkmez, 2021, s.182).

Yunus Emre'nin Risaletü'n- nushiyye'sini tamamladığı 707 (1307) yılı tarikata girdiği yıl olarak değerlendirilmektedir (Tatc1, 2013, s.602). Yunus Emre’nin mürşidi Tapduk Emre'dir, ancak Yunus'un mensup olduğu tarikat konusunda kesinlik yoktur. Yunus Emre’nin tarikatı konusunda değişik görüşler ileri sürülmüştür. Yunus'un tarikat pirleri dikkate alınarak Nakşi, Halveti, Mevlevi ve Kadiriliğe mensup olabileceği düşünülmüştür. Yunus, divanında tarikat silsilesini Tapduk Emre, Barak Baba ve Sarı Saltuk şeklinde kaydetmiştir. Ancak gerek Barak Baba’nın gerekse Sarı Saltuk’un gerçek kimlikleri ve tarikatları da bilinmemektedir (Tatc1, 2013, s.601). Yunus Emre'nin yaşadığı dönemde Anadolu'da faaliyet gösteren tarikatlar ise Kazerûniler, Evhadiler, Kübreviler, Vefailer, Rifailer, Ekberiler, Mevleviler, Bektaşiler ve Kalenderiler'dir (Ürkmez, 2021, s.183).

Yunus ve Tapduk Emre'nin Kalenderi mizaca sahip olmakla birlikte Batıni bir erkana bağlı olmadığı (Tatcı 2013, s.602) ve Yunus Emre'nin şiirlerinde on iki imamın adını kullanmaması da onun Sünni olabileceğini düşündürmektedir (Tatcı, 2013, s.601). Yukarıda adı geçen tarikatlar içinde Yunus Emre'nin mensup olabileceği tarikat olarak üzerinde en fazla durulan tarikatlar Mevlevilik ve Bektaşilik’tir (Tatcı, 2020, s.4).

Yunus Emre'nin bir şiirinde,

"Mevlana Hüda-vendigar bize nazar kılalı

Onun görklü nazarı gönlümüz aynası (oldu)" (Altınok, 2017, s.244) dediği cümlelerinden onun Mevlana’dan etkilendiği görülmektedir.

Yunus Emre'nin Hacı Bektaş Veli ile ilgili şiirinde ise; 
“Kundağının kulpu nurdan
Rızkı gelir Beytullahtan
Nesli paki Abdullah’tan
Hacı Bektaş Pirim Sultan.
Dervişleri konar göçer
Ab-ı zülalinden içer
Güvercin donunda uçar
Hacı Bektaş Pirim Sultan.
Kudretinden kaynar aşı
Gani cömert bir er kişi
Ervahı erenler başı
Hacı Bektaş Pirim Sultan.
Miskin Yunus bile vardı
Hikmetinden himmet aldı
Yeşil benli bir el gördü
Hacı Bektaş Pirim Sultan” (Altınok, 2017, s. 237-238).

Bahsedilen "Miskin Yunus bile vardı. Hikmetinden himmet aldı." cümleleri Yunus Emre'nin Hacı Bektaş Veli ile etkileşimini dile getirmektedir. Ancak Yunus Emre'nin benzer şekilde Mevlana'dan da bahsettiğini dikkate aldığımızda Yunus'un çağdaşları ile olan iletişimi ve etkileşiminin aynı yakınlıkta olduğunu göstermekle birlikte onun tarikatı hakkında kesin bilgi vermemektedir.

Yunus Emre zaviyesinin kuruluşu ve zaviyedarları.

Yunus Emre Zaviyesi Saru Köy'de ve aynı köyün mezrasında bir çiftlik yer "kadimden vakfiyat üzere" tasarruf edilmiştir. Zaviye ile ilgili erken tarihli kayıtlı bilgi 1466 tarihli Kirmasti defterinde yer almıştır. Burada İsa Bey zaviyenin gelirine katkı sağlamak için iki yerde çeltik ekilmesine izin verdiğini belirttiği mektu bulunmaktadır. İsa Bey 1444-1451 yılları arasında Anadolu Beylerbeyi olarak görev yaptı̆̆ için mektupta bu tarihlerde yazılmış olmalıdır. Vakıf kayıtlarında zaviyenin kadimden vakfiyet olduğu belirtilmesi ve 1444-1451 yılları arasında görevli olan İsa Bey'in mektubundan önce kurulmuş olduğu dikkate alındığında yapı Orhan Gazi dönemi ya da en geç I. Murad döneminde kurulmuş olmalıdır (Doğru, 1997, s. 109).

Yunus Emre zaviyesinin zaviyedarlığı ile ilgili 28 Safer 1257 tarihli beratta Seyyid Derviş Mustafa'nın vefatından sonra hizmetlerin aksadığı, Sarıköy halkının buradan göç etmesiyle Yunus Emre’nin türbesinden başka bina kalmadığı belirtilmiştir. Yapıya zaviyedarlık hizmetini yürütmek üzere Kadiri şeyhlerinden Sivrihisarlı Hacı Yakub oğlu Şeyh Mustafa atanarak türbenin imarı ve zaviye için gerekli odaların inşasını yaptırma görevi verilmiştir (Kunter, 2005, s. 105).

30 Mart 1850 tarihinde Ankara Evkaf Müdüriyeti'ne hitaben yazılan belgede zaviyedar Şeyh Mustafa bin Yakub'un vefat etmesiyle görevin küçük oğlu Yakub’a geçmesinin değerlendirildiği ve zaviye yönetiminin tarikatlar içinde yaygın bir kolu olan ve Abdülkadir-i Geylani’ye (ö. 561/1165-66) nisbet edilen Kadiriyye tarikatına (Azamat, 2001, 131) mensup olduğu belirtilmiştir (Topal, 2015, s.61).

Kadiriyye tarikatını Anadolu’ya 15. yüzyılda, Hacı Bayram-ı Veli’nin müridi iken onun emri üzerine Hama'ya gidip Abdülkadir-i Geylani’nin soyundan Hüseyin el-Hamevl'den hilafet alan Eşrefoğlu Rumi getirmiştir. 18. yüzyılda, Kadiriyye tarikatının Rumiyye kolu piri İsmail Rumi’nin çabaları sonucu başta İstanbul olmak üzere 
Anadolu ve Balkanlar'da yaygınlık kazanmış ve İsmail Rumi’nin İstanbul- Tophane'de kurduğu tekke diğer bölgelerde açılan Kadiri tekkelerinin merkezi olmuştur (Azamat, 2001, 132-133). 3 Kanun-1 Evvel 1326 (20 Aralık 2010) tarihli muhasebe koçanında zaviye ve türbenin iyi durumda olduğu kaydedilmiş ve mütevelli ve zaviyedar olarak Mustafa Kamil isminin geçtiğini, zaviyenin beratlı son temsilcisinin Sivrihisar'ın tabak esnafının başı olan ve Ahi Türk sıfatıyla anılan Yakub Bey’in oğlu Mustafa Kamil (Yakan) Efendi olduğunu belirtilmiştir (Kunter, 2005, s. 132, Topal, 2010, s.73).

Kadiriyye tarikatının Anadolu'da 15. yüzyılda yayınlaşmaya başlaması (Azamat, 2001, s.132-133) ve Yunus Emre zaviyesinin zaviyedarlığı için yapılan son atamanın Kadiriyye tarikatı yerine ahi teşkilatına mensup aileden yapılması Yunus Emre'nin bu tarikata mensup olma olasılı̆̆ını azaltmaktadır. Ayrıca Eskişehir'de de Odunpazarı yerleşiminde bulunan Şeyh Şehabettin Sühreverdi Zaviyesi'ne de Sühreverdi tarikatı yerine zaviyedar olarak Kanuni döneminde Hasan Fakih veledi Yakub vakfın başına getirilmiştir (Doğru, 2005, s.122). $\mathrm{Bu}$ farklı atamalar tarikatların ortaya çıkış ve yaygınlaşma dönemleri ile mevcut zaviyelere yapılan görevlendirmelerde o dönemin etkili olan tarikat veya teşkilatlarının atamalarda etkili olduğunu göstermektedir.

Zaviyedarların tarikatlarından yola çıkarak 15. yüzyılda yayınlaşmaya başlayan Kadiriye tarikatının silsilesine baktığımızda, Kadiriyye icazetnamelerinde tarikatın silsilesinin Hz. Ali’ye iki şekilde ulaştığı görülmektedir. Abdülkadir-i Geylani ve Ebu Said el-Muharriml'den başlayıp Ma'ruf-i Kerhl'ye kadar her iki silsiledeki isimler müşterektir. Ma'ruf-i Kerhl'den geriye doğru silsile imam Ali er-Rıza ve diğer Ehl-i beyt imamlarıyla veya Davud et-Tai Habib el-Acemi, Hasan-1 Basri yoluyla Hz. Ali’ye ulaşır. (Azamat, 2001, s.133).

Kadiriyye tarikatının Anadolu'daki gelişimi Yunus Emre'nin yaşadığı dönemden sonra olması ve şiirlerinde on iki imamın adını kullanmaması onun Sünni olabileceği (Tatcı, 2013, s. 601-602), ayrıca Yunus ve Tapduk Emre'nin Kalenderi mizaca sahip olmakla birlikte Batıni bir yapıya bağlı olmadığı genel kabul görmektedir (Tatcı, 2013, s. 601-602). Anadolu Selçuklu ve Osmanlı dönemi yerleşimi olan Odunpazarı semtinde de Kadiri tekkesi veya onun 46 ayrı kolundan birine mensup bir zaviye tespit edilmemiştir.

Türkyılmaz (2010), Yunus Emre'nin hiçbir tarikatın üyesi ve kurucusu olmadığını savunur. Ona göre "Yunus Emre bütün tarikatların saygıdeğer, öncü, pir, veli kabul ettikleri bir mutasavvıf şairdir. Şiirlerinde sürekli olarak farklılıkları hoş görmeyi, Allah'ın kullarında Allah’ı görmeyi vurgulamış, bu inançla belirli bir grubun temsilcisi veya üyesi olmamış, birleştiriciliği ve uzlaşmayı temsil etmiştir” (Türkyılmaz, 2010, s.47) açıklamalarında olduğu gibi Yunus Emre'nin ister yaşadığı dönemdeki tarikatlarından ister zaviyesinde görev yapan tarikat mensuplarından yola çıkalım onun tarikatını şu an için kesin olarak tespit etmek mümkün görünmemektedir.

Eskişehir kent merkezinde bulunan zaviyeler ve tarikatları.

Orta Asya'dan Anadolu'ya göç eden Türkler arasında bulunan şeyh ve dervişler yeni topraklarda tasavvufun temelini atmışlardır. Selçuklu hükümdarları, Anadolu'ya gelen bu dervişlere sahip çıkarak, onların faaliyetlerine imkan tanımışlardır (Çelik, 2017, s.54).

Uç şehirlerden olan Eskişehir'in fetih ve iskan hareketleri için geçiş noktası olması nedeniyle Eskişehir ve çevresinde de pek çok zaviye kurulmuştur. Anadolu Selçuklu Devleti döneminden itibaren kurulmaya başlayan bu zaviyelerin bir kısmı Cumhuriyet dönemine kadar varlıklarını sürdürmüştür.

Eskişehir ve çevresindeki zaviyelerin en erken tarihlisi Şeyh Şehabeddin Sühreverdi zaviyesidir. Bu zaviye Alaeddin Keykubad'ın tahta geçişini kutlamak ve kendisine fütüvvet şalvarını giydirmek üzere Abbasi Halifesi Nasır Lidinillah’ın Konya'ya gönderdiği Şeyh Şehabeddin Sühreverdi adına Eskişehir'de yaptırılmıştır. Alaeddin Keykubad 1219-1236 yılları arasında saltanatta bulunduğundan zaviye de bu yıllar arasında inşa edilmiş olmalıdır (Topal ve Çolak, 2015, s.55). 
Şeyh Şehabeddin Sühreverdi zaviyesinden sonra tarihi takip edilebilen ikinci zaviye Şeyh Abdullah el Bedevi zaviyesidir.

Eskişehir valisi iken 1261 yllında Kırşehir'e vali tayin edilen Nureddin Cibril bin Caca Bey, Eskişehir'den ayrılmadan önce şehrin imarı ile ilgilenmiştir. Caca oğlu şehirdeki 17 mescit ile Şeyh Abdullah el Bedevi’ye ait zaviyeyi de tamir ettirmiştir (Caca Oğlu Nur El-din, çev.1989, s.11).

Erken tarihli bu iki zaviyeden sonra da Eskişehir ve çevresinde değişik tarihlerde birçok zaviye inşa edilmiş ve zaviye sayısı tespit edilebildiği kadarıyla 124'e ulaşmıştır (Topal ve Çolak, 2015, s.55).

Şehabeddin Sühreverdi zaviyesi.

Şeyh Şehabeddin Sühreverdi Zaviyesi'nin, özgün yeri kesin olarak bilinmemekle birlikte, Doğru (1991), Fatih Sultan Mehmet Dönemi vakıf defterlerinde "Vakıf-ı kadim" olarak yazılmasına dayanarak zaviyeyi Selçuklu devrine tarihlendirmiştir (Doğru, 1991, s.40). Günümüze ulaşamayan zaviye halk arasında Salı Tekkesi olarak bilinmektedir. Zaviyenin bugünkü türbenin yerinde olduğu genel kabul görmektedir. Kitabesi mevcut olmayan yapı (Büyükoksal, 2012, s.80), Odunpazarı Semti, Paşa Mahallesi, Kemal Zeytinoğlu Caddesi'nde 17 numarada yer almaktadır (Şekil 4).

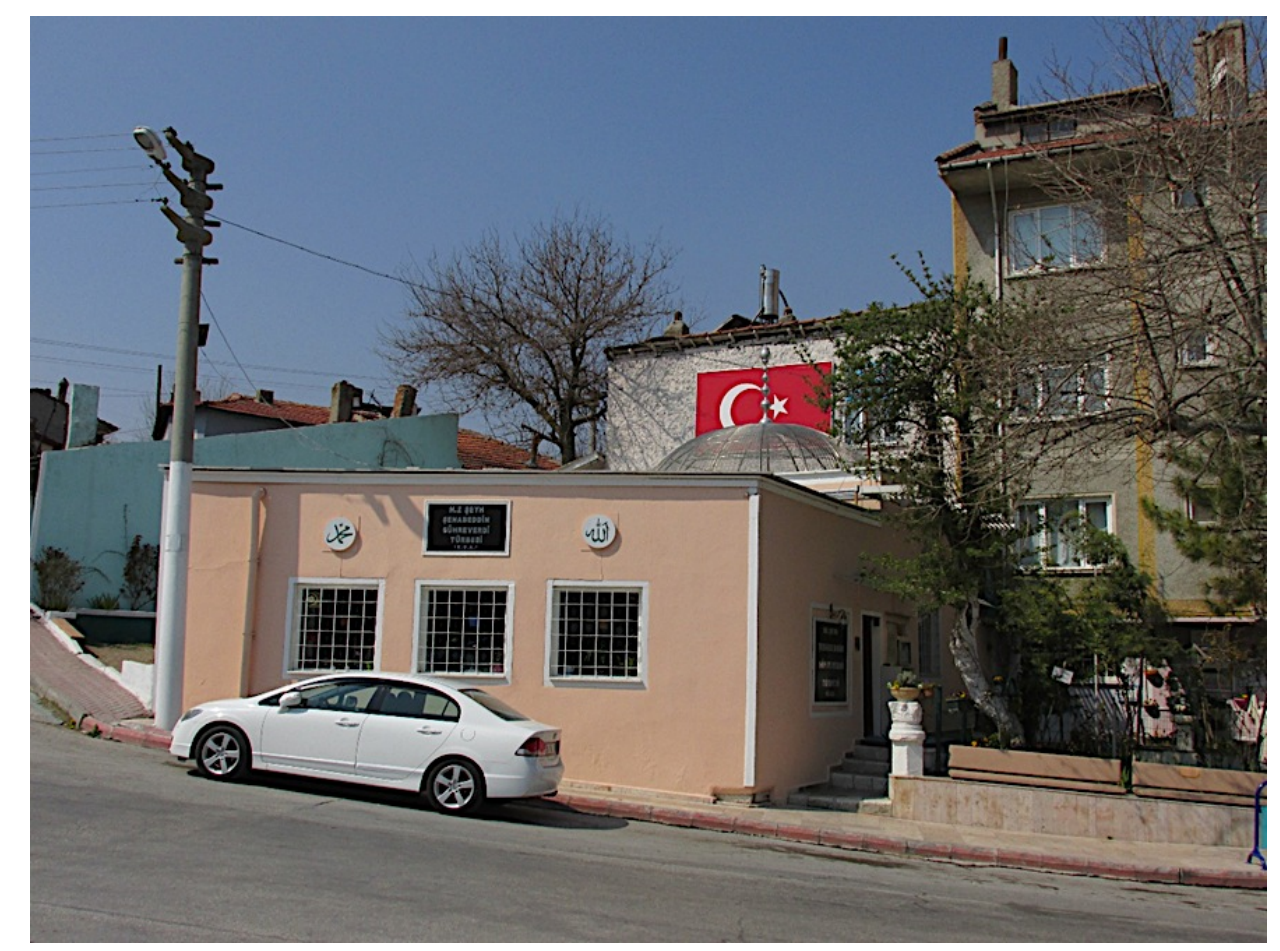

Şekil 4. Şeyh Şehabeddin Sühreverdi Zaviyesi’nin bulunduğu yer olduğu kabul edilen Türbe (Manaz, 30 Mart 2019).

1984 yılında türbenin tahrip olan ahşap çatısı, kırma çatılı olarak yenilenmiş ve duvarları tamir edilmiştir. 2009 yılında yapılan onarımla da doğu cephesine üç pencere açılmıştır (Altınsapan ve Parla, 2010, s. 19).

Türbe, dikdörtgen tabanlı, içten çıtalı düz ahşap tavanlı, dıştan düz çatı üzerine yerleştirilen çelik iskeletli şeffaf bir kubbe ile kapatılmıştır. Kuzey cephesinde yer alan kapıdan girilen türbenin doğu cephesinde üç, kuzey cephesinde bir adet dikdörtgen şeklinde ahşap kasalı pencere vardır. 
Sühreverdiyye tarikatının kurucusu $\mathrm{Hz}$ Ebubekir soyundan Şeyhü’ş-şüyûh unvanıyla anılan, Nasıriyye, Bistamiye ve Me’mûniyye tekkelerinin şeyhliğini de yapmış bulunan Şeyh Şehabeddin Sühreverdi (öl.1234), Halife Nasır-Lidinillah döneminde fütüvvet teşkilatının organize edilmesine öncülük etmiştir (Manaz, 2019, s.128).

\section{Abd Allah el Bedevi zaviyesi.}

Abd Allah el Bedevi'ye nispet edilen zaviye, Caca oğlu vakfiyesinde adı geçen Sultaneyüğü'nde Selçuklu döneminde kurulduğu kesin olarak bilinen tek zaviyedir. Kuruluş tarihleri kesin bilinmeyen Şeyh Şehabeddin Sühreverdi, Şeyh Edebali, Ahi Mahmud ve Şeyh Nusrettin zaviyeleri, vakıf kayıtlarında kadimden yapılar olarak kaydedildiği için Selçuklu dönemine ait yapılar oldukları kabul edilmektedir (Manaz, 2019, s.125).

Mısır'da Ahmediye adıyla da bilinen Bedeviyye tarikatini kuran Seyyid Ahmed el-Bedevi, 1200 yılında Fas'ta doğmuş, 12 Rebiülevvel 675/1276 tarihinde Tanta'da vefat etmiştir (Manaz, 2019, s.126).

Abd Allah el Bedevi Zaviyesi hakkında 1272 tarihli Cacaoğlu Vakfiyesinde;

"Meşhur zahid ve abidelerden Şeyh Abd Allah el-Bedevi'ye nispet edilen zaviyenin ihtiyaçları da bu vakıflardan temin edilir. Vakıf bu zaviyeyi yeni baştan tamir ettirmiştir” (Caca Oğlu, 1272, çev. 1986, 128) açıklaması bu zaviyenin Selçuklu döneminde harap halde olduğunu göstermektedir. Caca Oğlu 1262 yılında Kırşehir valiliğine atanmadan önce Eskişehir'de vali olarak görev yaptı̆̆g göz önüne alındığında Şeyh Abd Allah el Bedevi'ye nisbet edilen zaviye 1261 yllında harap haldeyken onarıldığından zaviyenin kuruluşunun 1261 tarihinden daha erken tarihte olduğu öğrenilmektedir.

Caca oğlu vakfiyesinde onarıldığı bildirilen Şeyh Abd Allah el Bedevi'ye nisbet edilen tahrip olmuş zaviye dışında herhangi bir zaviye adı yer almamıştır.

Doğru (2005), Şeyh Abd Allah el Bedevi Zaviyesi'nin Fatih döneminde 50 dönüm yer ve Dut Eyyügü̈nde bir pare yer Ahi Mehmet oğlu Hoca'nın tasarrufunda, buranın tımara çevrilen vakıflardan olduğunu ve Kanuni Sultan Süleyman döneminde Hamza Fakifin oğulları Derviş Ali ve Derviş Mehmed'in tasarrufuna bırakıldığını, ancak zaviyenin yerinin tespit edilemediğini belirtmiştir (Doğru, 2005, 123). Doğru (2005), ayrıca Ak Togan (Doğan) adlı zaviyenin tarihlendirilmesini kayıtlarda "kadimden vakfiyet üzere tasarruf olunur" beyanına dayanarak Anadolu Selçuklu dönemine tarihlemiştir. Zaviyeye 80 dönüm yer ve mülk değirmen vakfedilmiştir. Zaviyenin yeri hakkında bilgi verilmezken değirmenin yerinin de belli olmadığını ve II. Bayezid döneminden itibaren harap durumda olduğunu belirtmiştir. Doğru (2005), suyla çalışan bu değirmenin şehri yakın bir yerde ve Porsuk Çayı üzerinde olabileceğini düşünmüştür (Doğru, 2005, 123).

Ahmet Tevhit'in, Cacaoğlu Nureddin'in yaptırdığı Odunpazarı yerleşiminin eteğinde, yer alan Alaaddin Camii'nin yıkık minare kitabesi için hazırladığı raporunda “Abdullah Bedevi'nin zaviyesi harap olmuştur, ancak Sultan Abdullah namı diğeri Ak Doğan ismiyle yeniden yapılmış bir türbe bulunmaktadır. Bu türbe Eskişehir'in yukarı semtinde Karapınar Mahallesi'nde mustakil küçük bir binadır. Civarında temel, direk ve sair asarı bakiyesi görülmemektedir” (İhsan, 1934, s.263-268, Manaz, 2019, s.126) şeklindeki açıklama günümüze ulaşamayan Abdullah Bedevi-Sultan Abdullah-namı diğeri Ak Doğan'ın aynı kişi olduğu ve Doğru'nun (2005), yerinin belli değil dediği yapının bu raporla Odunpazarı’nda Karapınar Mahallesi'nde yer aldığı (Şekil 5) tespit edilmiştir. 


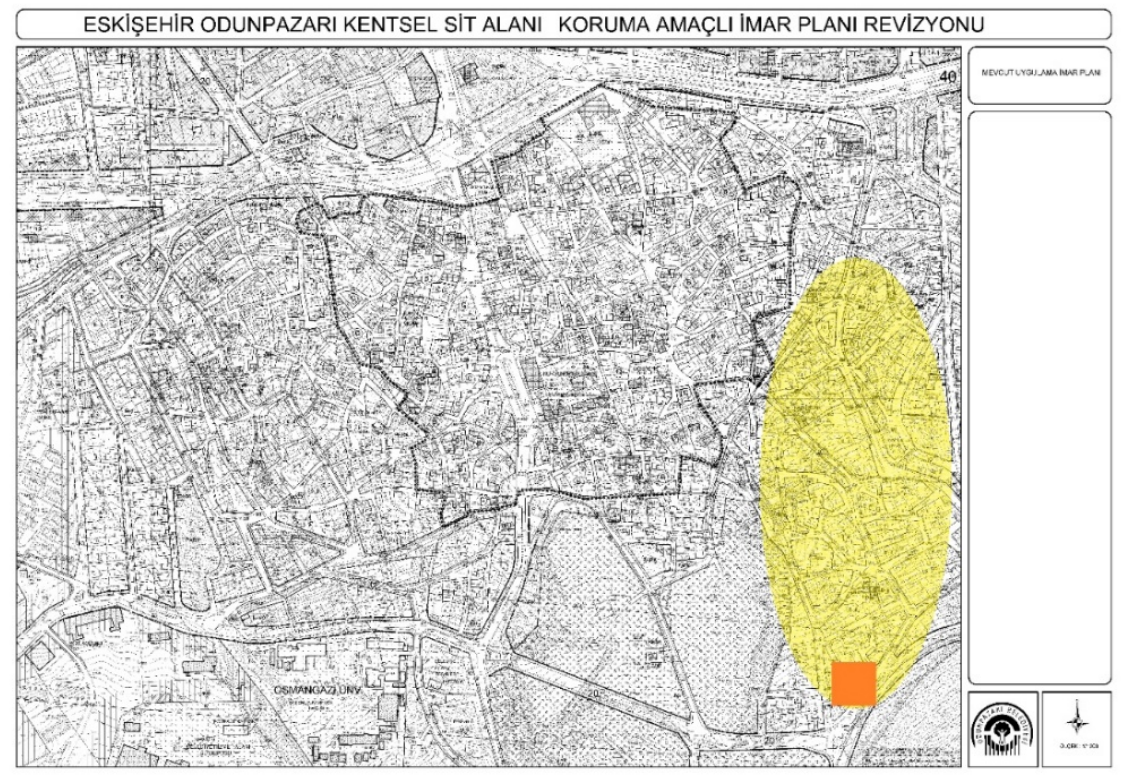

Şekil 5. Karapınar Mahallesi Şeyh Abd Allah el- Bedevi Zaviyesi ile Türbesi'nin muhtemel yeri (Manaz, 2019).

Günümüzde Karapınar Mezarlı̆ğ'nın önünde bulunan Öğütçü Sokak 1 Numaralı yerde 1526 tarihinde Mustafa Paşa tarafından yaptırıldığı düşünülen, (Kılcı, Erat, Alevsaçar Köse, Topkaraoğlu, Yiğit İncifırat ve Özçelik, 2000 öncesi) ve önünde çeşmesi bulunan Karapınar Camii (Şekil 6) yer almaktadır. Şeyh Abd elBedevi Zaviyesi’nin de bu caminin bulunduğu bölgede olma ihtimali oldukça yüksektir. Caminin arka tarafında içinde Şeyh Edebali’nin Makam Türbesi'nin de yer aldığı Odunpazarı mezarlığı (Şekil 7) güneye doğru devam etmektedir.

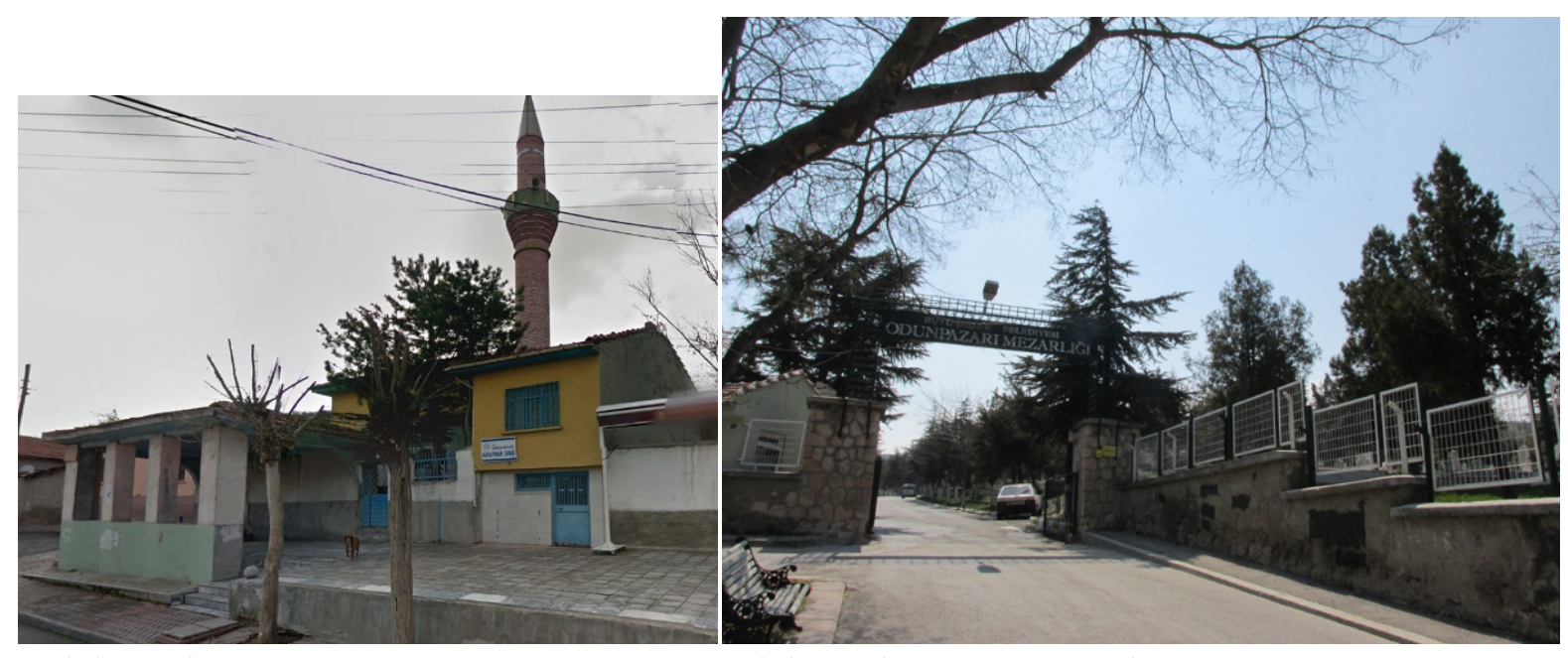

Şekil 6. Odunpazarı Karapınar Camii

Şekil 7. Odunpazarı Mezarlığı (Manaz,30 Mart 2019).

Doğru (2005)'nun vakfedilenler arasında belirttiği yeri belli olmayan ve su ile çalışan değirmen ise detay verilmemekle birlikte Caca Oğlu Nur El-din'in 1272 tarihli vakfiyesinde geçmektedir. 
“Cacaoğlu Nureddin’in Vakfiyesi’nde vakfettiği:

“iki değirmen ve sebzelik, meyvalı ağaçları bulunan bahçe ve değirmenlerden birine bitişik olan bir parça arazinin tamamı. Sofa ile yedi tane odanın, sekiz odalı etrafı taşla çevrili yerin ve bunlarla ilgili olan her şeyin tamamı olup, bunlardan her biri dört taraftan çevrilmiştir; bir taraftan İlyas'ın mülkü ile diğer taraftan Ebi Nemre'nin mülkleriyle, üçüncü taraftan çayırlıkla ve yolla sınırlanmıştır” (Caca Oğlu, 1272, çev. 1986, 127) açıklamasından Cacaoğlu vakfiyesinde Selçuklu Dönemi’nde Eskişehir'de en az iki yerde değirmen olduğunu kesindir.

“Diğer bir parça arazinin tamamı olup, sınırı ırmağa, Abdullah vereseleri mülkü ile Emir Ali’nin mülküne ve değirmenin su aldığı akar suya kadar uzanır” (Cacaoğlu, 1272, çev. 1989, 127, 128) açıklaması ile değirmenin su aldığı akar sudan bahsedilmiş olması günümüzde mevcut olmayan, kaynağını Porsuk Çayı'ndan alarak Akarbaşı'ndan Hamam Yolu Caddesi'ne uzanıp sıcak sular bölgesinde yine Porsuk Çayı'na karışan Akar Deresi (Şekil 8) üzerinde bulunan değirmenin olduğuna işaret etmektedir. Günümüzde mevcut olmayan değirmenin Matrakçı Nasuh’un minyatüründe gördüğg̈müz (Şekil 9) Akarbaşı semtinde bulunan Akar Deresi üzerindeki değirmen olmalıdır.

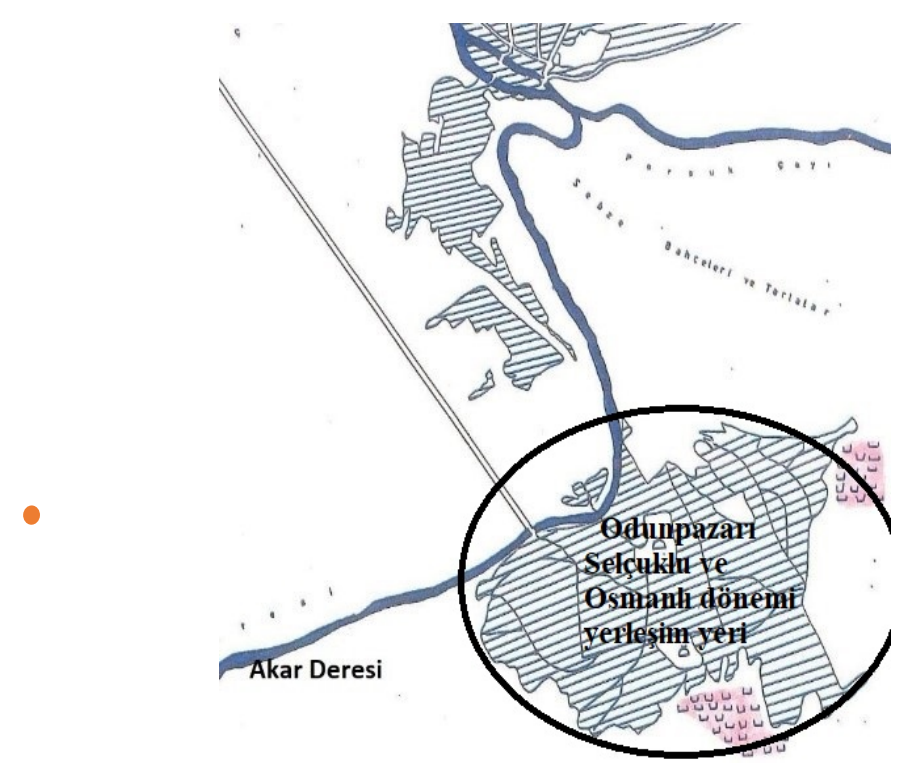

Şekil 8. Kaynağını Porsuk Çayından alarak Akarbaşı semtinden Hamamyolu Caddesinden Sıcak Sular Bölgesinde yine Porsuk Çayına karışan Akar Deresi (Ertin, 1994). 


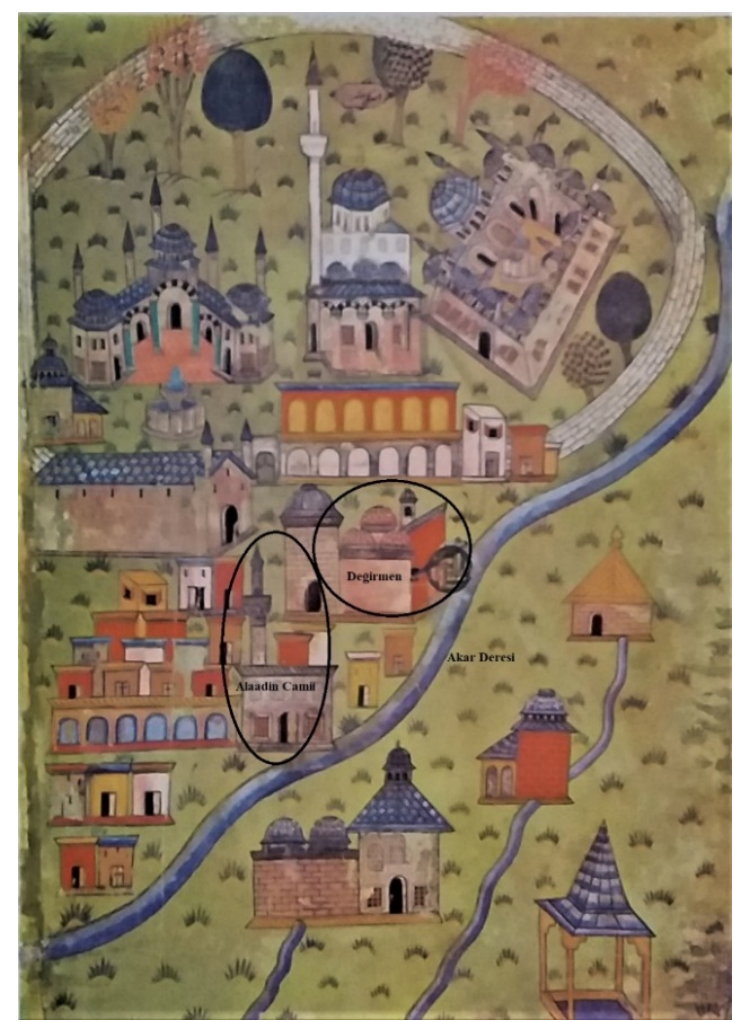

Şekil 9. (Martakçı Nasuh, 1534, çev. 2014).

Şeyh Edebali zaviyesi.

Şeyh Edebali Zaviyesi hakkında 1466 tarihli belgede zaviyenin harap durumda olduğu belirtilmiştir. 1520 tarihli vakıf kayıtlarında ise Eskişehir'e bağlı Karacadeğiş Köyü’nde Şeyh Edebali Zaviyesi'ne bağlı bir vakıf çiftliğinin bulunduğu, Fatih Sultan Mehmet tahta geçtiğinde (1451) zaviyenin harap durumda olduğu, vakıflar iade edilirken çiftliğin Ahi Ede Zaviyesi'ne iade edilmeyerek satın alma yoluyla Seyitgazi Tekkesi'ne vakfedilmiş olması, zaviyenin varlığını 16. yüzyıla kadar sürdürdüğünü göstermektedir. Fatih dönemine kadar izlenebilen vakıf kayıtlarında zaviyenin adı "Ahi Ede" olarak geçmektedir (Manaz, 2019, s.128-129, Altınsapan, 1999, s.11-12).

Ahi Şeyhi olan Edebali'nin (1206-1326) Odunpazarı semtinde bir makam türbesi bulunmaktadır (Şekil 10). Asıl türbesi ise Bilecik'te yer aldığından Eskişehir'de kitabesi bulunmayan makam türbesinin şeyhin ölümünden (1326) sonra, 14. yüzyılın ortalarında yapılmış olacağı düşünülmekle birlikte (Kapadokya Mimarlık, 2007), mimari özellikleri dikkate alınarak 14. yüzyılın ilk çeyreğine tarihlenmektedir (Kılcı, ve diğerleri, 2000 öncesi). 


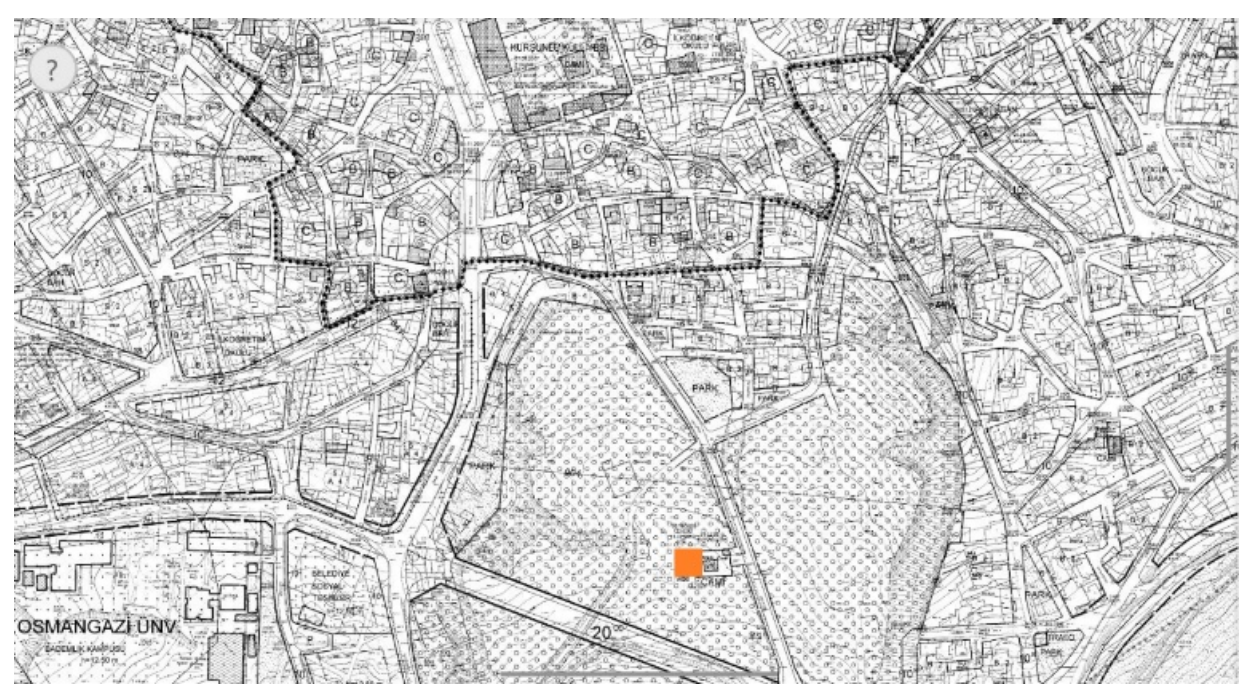

Şekil 10. Odunpazarı Mezarlığı Şeyh Edebali Türbesi’nin konumunu (Manaz, 2019).

Odunpazarı mezarlığının içinde yer alan Şeyh Edebali’nin makam türbesi (Şekil 11) doğu-batı doğrultusunda dikdörtgen tabanlıdır. Türbe, iki yandaki tonozlara oturtulmuş sekizgen kasnağa sahip kubbeyle örtülmüştür. Kesme taştan inşa edilen türbeye batı cephesindeki kapıdan girilmektedir. Doğu ve güney cephelerinde dikdörtgen şeklinde birer penceresi bulunmaktadır. Türbenin içinde yer alan mihrabın önünde ahşap bir sanduka bulunmaktadır. Şeyh Edebali'nin makam türbesinin (Eskişehir Kültür ve Tabiat Varlıklarını Koruma Kurulu, Doğal ve Kültürel Varlıklarını Koruma Envanteri Envanter no: 22.) büyük ihtimalle Şeyh Edebali’nin sağ iken en erken 1220-1230'lu yıllarda, en geç Sultaneyüğü şehrinin (Eskişehir) Osmanlılara geçtiği tarihte kurulmuş olması gereken Şeyh Edebali Zaviyesi'nin yerine sonradan makam türbesinin inşa edildiğini ileri sürmek mümkündür (Manaz, 2019, s.130).

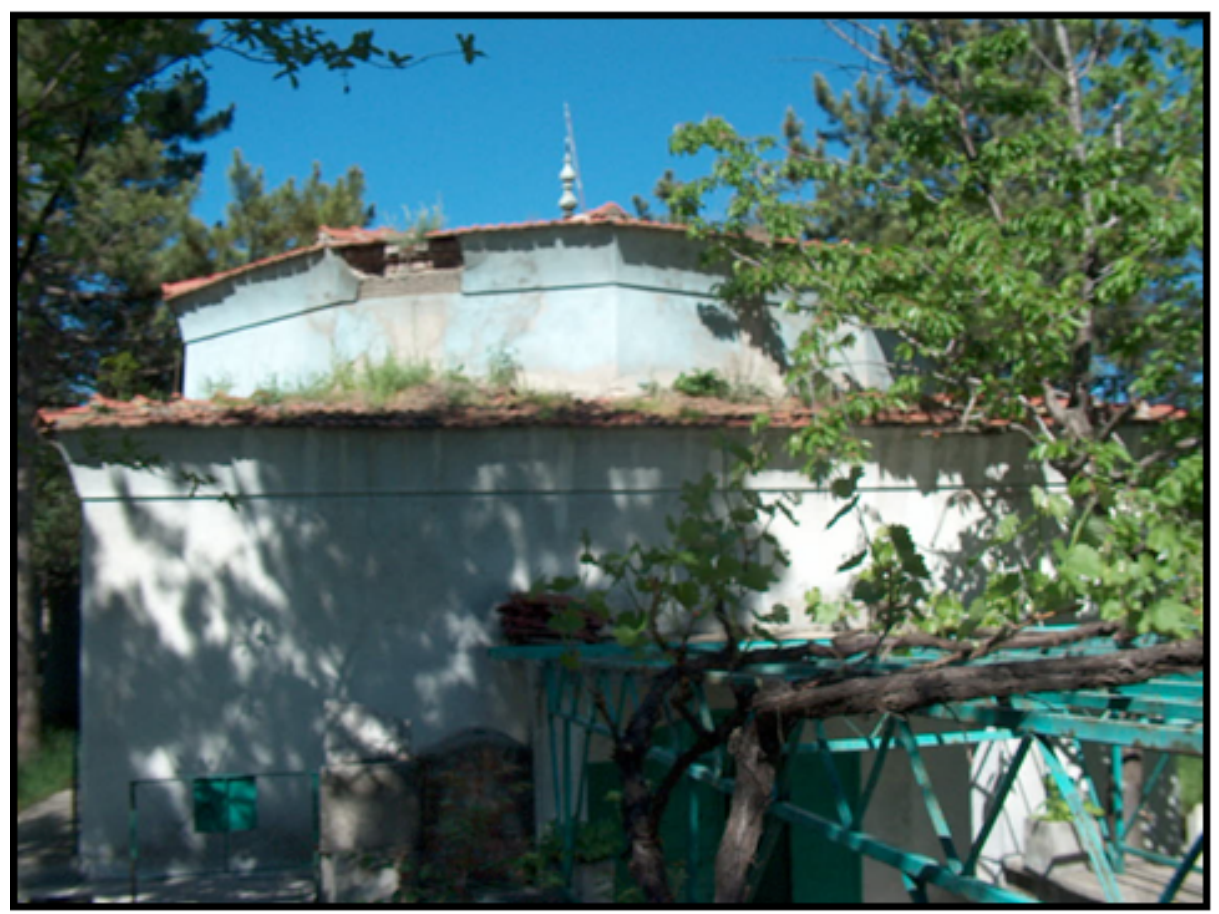

Şekil 11. Şeyh Edebali Türbesi (Kapadokya Mimarlık, 2007). 
Hakkında farklı görüşler bulunmakla birlikte Tacü’l-arifin Ebül-Vefa Bağdadi (1107)'nin kurucu piri olduğu Vefaiyye tarikatına mensup olduğu kabul edilen Şeyh Edebali'nin Sultaneyügü̉ne ne zaman yerleştiği kesin olarak bilinmemekle birlikte, günümüzde Eskişehir’in Çukurhisar ilçesi Uludere Köyü (İt Burnu) bölgesinde ikamet ettiği kabul edilmektedir (Erdoğan, 2015, s.314, 327).

Ahi Mahmud zaviyesi.

Ahilik teşkilatının, Abbasi halifesi Nasır li-Dinillah’ın, Anadolu Selçuklu Sultanı I. Keykavus'u 1216 tarihinde fütüvvet teşkilatına almasından sonra Anadolu'ya geldiği ve 14. yüzyıldan itibaren de Anadolu'nun her yerinde ahi zaviyelerinin kurulduğu görülmektedir. (Ocak, 1978, 259).

Ahi Mahmud Zaviyesi, Osmanlı Arşivi Maliyeden Müdevver fonunda 1525-1528 tarih aralığına ait kayıtların bulunduğu 27 numaralı defterde yer alan; "Karye-i Şehr Öyüğü, "Karye-i mezkûrede Ahi Mahmud Çiftliği kadimden vakfiyyet üzre" şeklindeki ifadeye dayanılarak Selçuklu Dönemi ya da Osmanlı'nın kuruluş yıllarında tarihlendirilmektedir (Manaz, 2019, s.131).

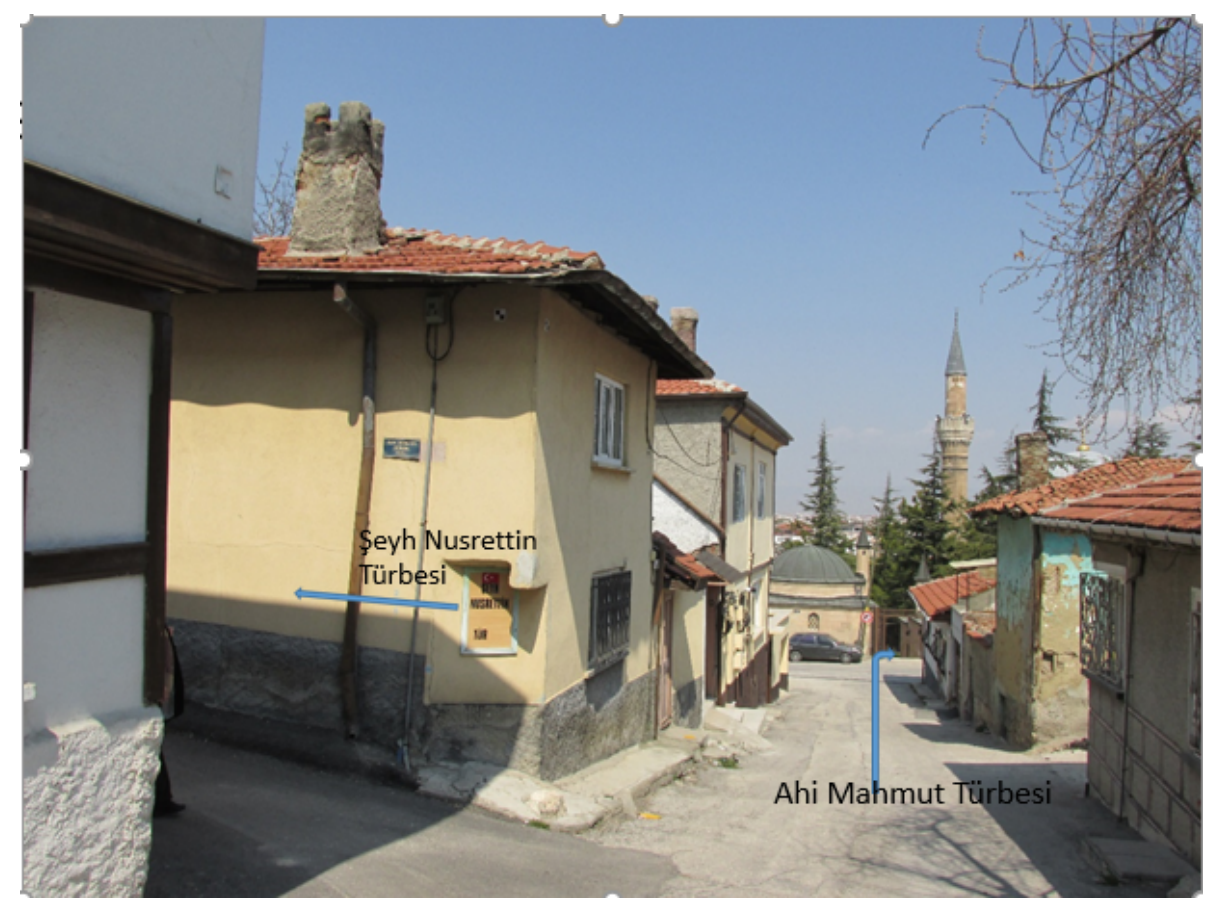

Şekil 12. Şeyh Nusrettin Türbesi ve Mahmut Türbesi (Manaz, 30 Mart 2019).

Günümüze gelemeyen Ahi Mahmud Zaviyesi’nin, Yeşil Efendi adıyla anılan türbesi, Odunpazarı Semti, Dede Mahallesi, Kurşunlu Külliyesi arkasında batı ucunda yer almaktadır (Şekil 12.- Şekil 13.).

Ahi Mahmud Zaviyesi’ne ait kayıtlara bakıldığında 23 dönüm yere Fatih döneminde el konulup tımara verilmiş iken, daha sonra II. Bayezid döneminde zaviyeye geri verilmiştir (Topal, 2012, s.6-8). 


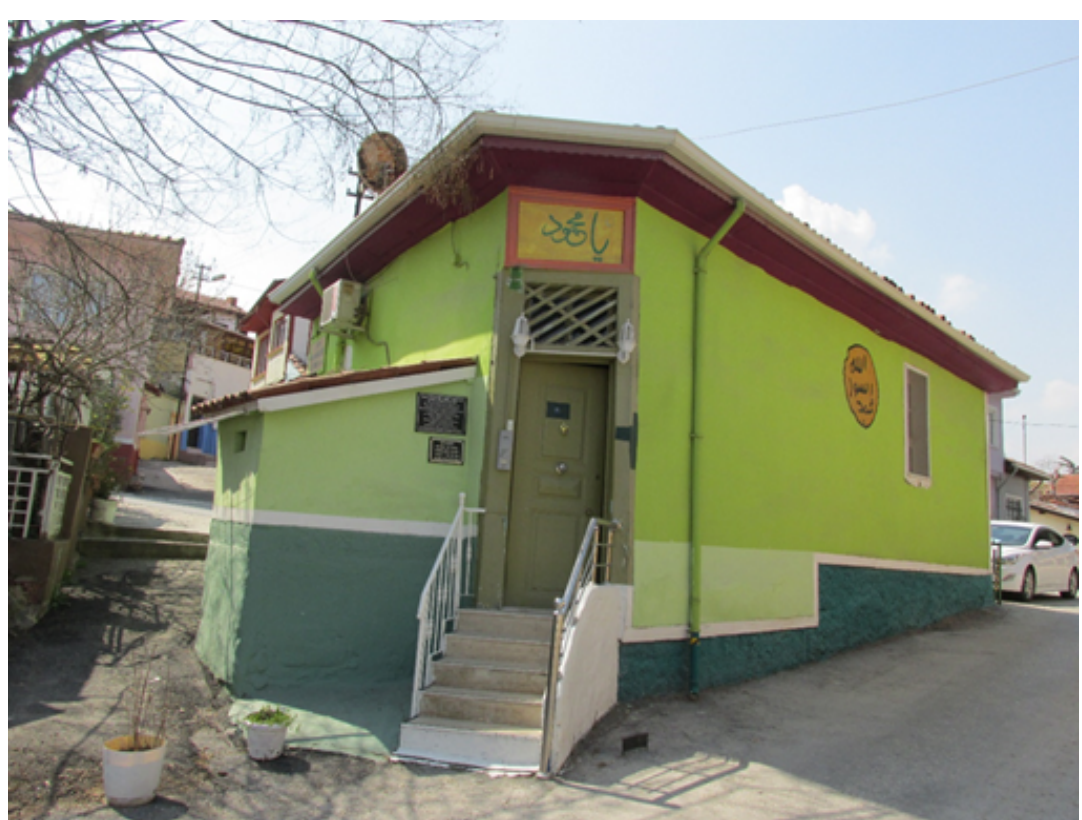

Şekil 13. Ahi Mahmud Türbesi (Manaz, 30 Mart 2019).

\section{Şeyh Nusreddin zaviyesi.}

1912 yılında Eskişehir’i ziyaret eden Mehmet Ziya tekkenin varlığından bahsetmiştir. Burası Fatih Sultan Mehmet döneminde Şeyh Şehabeddin zaviyesi ile aynı vakıf gelirlerine sahip olmuştur. Ancak yol genişletme çalışmaları sırasında zaviye ve haziresindeki mezarlar yok olmuştur. (Doğru, 2005, s.124-125). Günümüzde Kurşunlu Külliyesi’nin güneyinde aynı adla bir türbe yer almaktadır (Şekil:14).

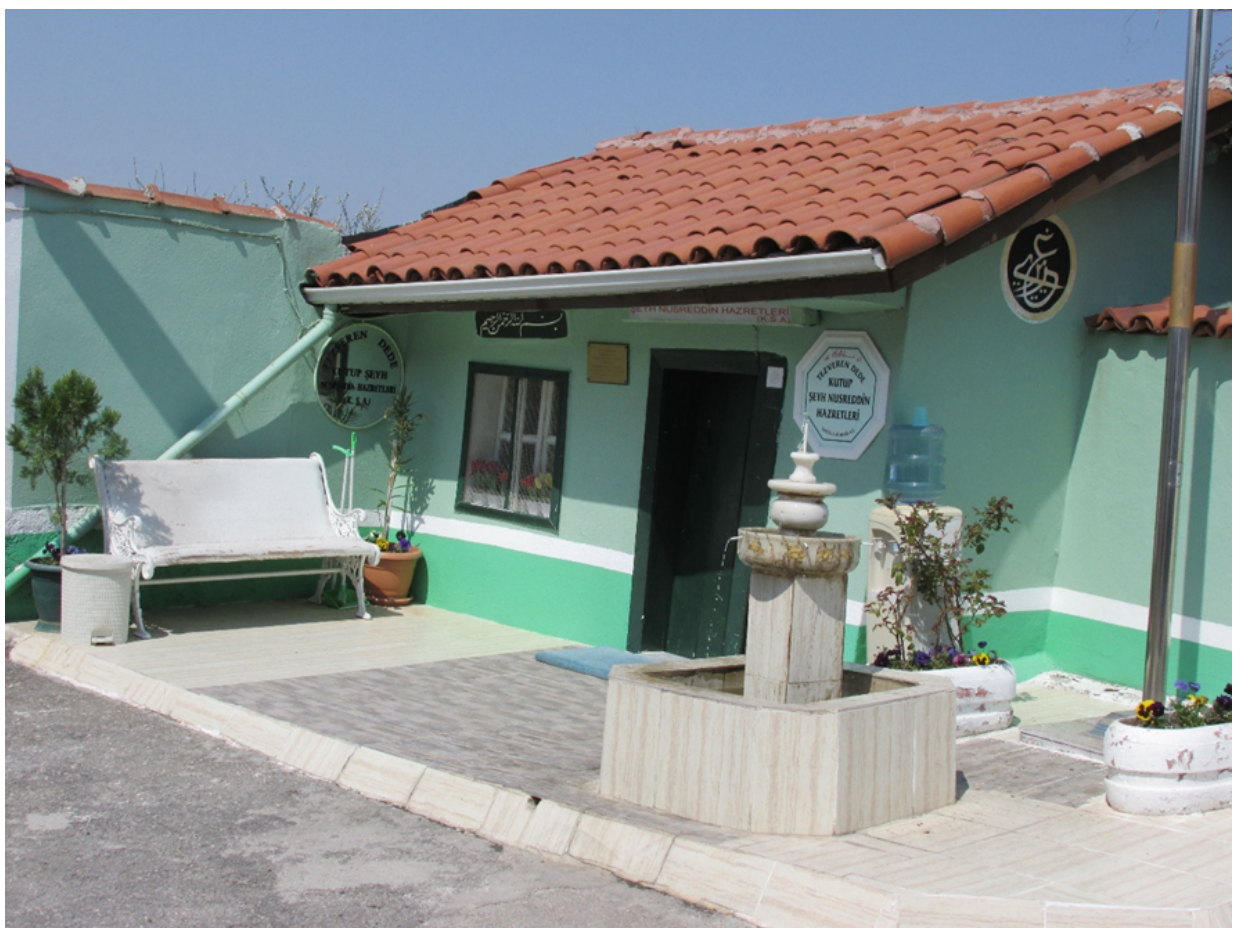

Şekil 14. Şeyh Nusrettin Türbesi (Manaz, 30 Mart 2019). 
Şeyh Nusrettin'in mensup olduğu veya olabileceği tarikat hakkında şimdilik bir bilgi yoktur. Ancak günümüzde Şeyh Nusreddin olarak bilinen ismi Doğru (2005), zaviyeyi tanımlarken Hacı Nusreddin başlığını kullanarak Osmanlı arşivinde yer alan kayıtlardan bilgi vermiştir (Doğru, 2005, s.124).

Zaviyenin Selçuklu döneminde inşa edilip edilmediği kesin olarak bilinmemektedir. Başbakanlık Osmanlı Arşivi Daire Başkanlığı Maliyeden Müdevver fonunda 27 numara ile kayıtlıdır. Topal (2011), 1525-1528 tarih aralığına ait kayıtların yer aldığı bu defterdeki Hacı Nasreddin Zaviye’siyle ilgili olarak şu bilgileri vermektedir;

"Bir çiftlik yerdir kadimden vakfiyyet üzre merhûm Sultan Mehemmed Han (Fatih Sultan Mehmet 1451-1481) beratıyla Mehmed veled-i Hasib ve Mustafa birader tasarruf ederken mensûh olub timara verilmiş Ba'dehû vakfiyyeti mukarrer dutulub İbrahim ve Seydi Ahmed ve Yusuf mutasarrıflardır deyü kaydolunmuş der-defter-i atik el-haletü hazihi zaviye-i mezkûra berat-1 şahi ile Seyyid Kasım mutasarrıf deyü kaydolunmuş der-defter-i köhne elan kezalik"(Topal, 2011, s.75).

Verilen bu bilgilere göre zaviye Fatih Sultan Mehmed (1451-1481) dönemi öncesinde en geç 14. yüzyll sonlarına, hatta 13. yüzyıla tarihlemek mümkün olmaktadır (Topal, 2011, s.75, Manaz, 2019, s.132). (Şekil 15.).

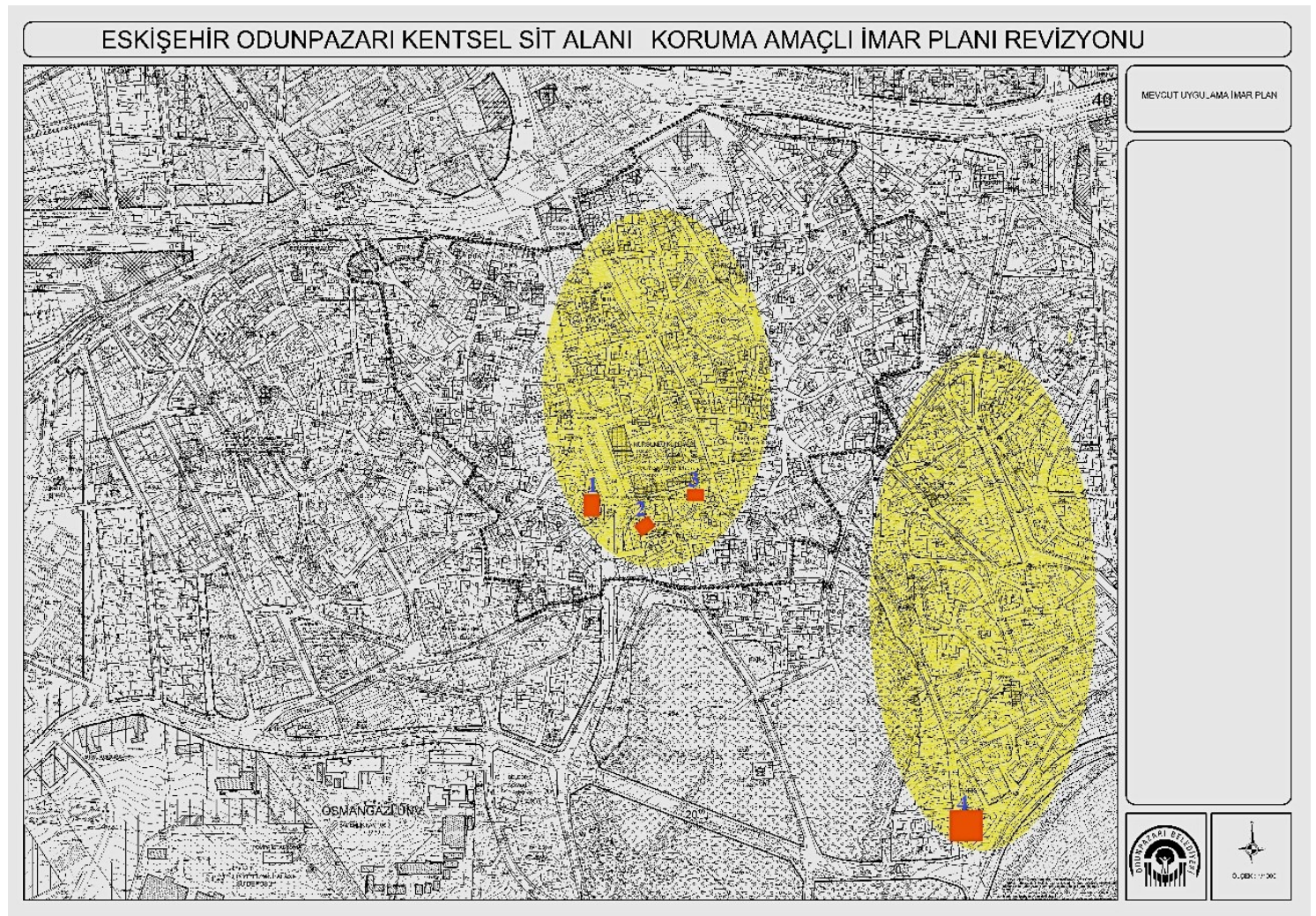

Şekil 15. Yaklaşık 2km. alan içerisinde kurulan Selçuklu devri zaviyelerinin günümüze gelebilen türbelerinin konumunu gösterir harita. (1-Şeyh Şehabeddin Sühreverdi Zaviye Türbesi, 2- Şeyh Nusrettin Zaviye Türbesi, 3-Ahi Mahmud Zaviye Türbesi, 4-Şeyh Abd Allah el-Bedevi Zaviye Türbesi. (Manaz, 2019). 


\section{Sonuç}

Yunus Emre’nin yaşadığı (1240-1321) dönem Anadolu Selçuklularının son yılları ve isyanların, akınların yaşandığı huzursuz bir ortam vardır. Bu dönemde gerek Anadolu dışında oluşmuş tarikatların temsilcileri ile kurulan tarikatlar gerekse Anadolu'da kurularak gelişen tarikatların sayılarında artış olmuştur. Böylece Anadolu'da oldukça geniş yelpazeli bir tarikat sistemi oluşmuştur.

Yunus Emre’nin tarikat pirleri dikkate alınarak bağlı olabileceği tarikatı konusunda değişik görüşler ileri sürülmüş olsa da silsilesinde bulunanların da gerçek kimlikleri ve tarikatları da kesin belli değildir. Mensup olabileceği kabul edilen bazı tarikatlar ise onun yaşadığı dönemden sonra Anadolu'da yayılmaya başlamıştır. Yunus Emre'nin adına kurulan zaviyesi dikkate alınarak mensup olabileceği tarikatına baktığımızda ise, zaviyenin kuruluş tarihine ait en erken kayıtlar 15. ve 16. yüzyıla aittir. Ancak vakıf kayıtlarında zaviyenin kadimden vakfiyyet üzere olduğu belirtildiği için zaviyenin kuruluşu, Orhan Bey dönemi veya en geç I. Murad dönemine tarihlenebileceği genel kabul görmektedir. Zaviyeye yapılan zaviyedar atamalarında 21 Nisan 1841 tarihli beratta Seyyid Derviş Mustafa'nın vefatından sonra zaviyedarlık hizmetine Kadiri şeyhlerinden Sivrihisarlı Şeyh Mustafa bin Yakub atanmıştır. Ancak 20 Aralık 1910 tarihinde zaviyedar olarak Mustafa Kamil (Yakan) Efendi'nin ataması ve onun babası Yakub Bey’in Sivrihisar'ın tabak esnafının başı ve Ahi Türk olarak anılmasından dolayı Yunus Emre’nin zaviyesinin kurulduğu dönemde, 15. yüzyılda yayınlaşmaya başlayan Kadiri tarikatından atama yapıldıktan sonra Ahi soyundan gelen birinin zaviyedar olması yaşanılan dönemde aktif ve etkili olan tarikatların bu zaviyeyi benimsedikleri, dolasıyla Yunus Emre'nin Kadiri tarikatına mensup olamayacağını da göstermektedir.

Yunus Emre’nin yaşadığı dönemde Sultaneyügü/Sultanöyüğü adı ile anılan Selçuklu ve Osmanlı dönemi yerleşim yeri olan Odunpazarı bölgesinde de Yunus Emre’nin yaşadığı dönemdeki zengin tarikat yapısı ile paralel olarak birbirinden farklı tarikatlara mensup Şeyh Şehabeddin Sühreverdi, Şeyh Abdullh Bedevi, Şeyh Nusreddin, Şeyh Edebali ve Ahi Mahmud zaviyeleri yaklaşı $2 \mathrm{~km}$ 'lik alanı kapsayan yerleşim bölgesi içerisinde varlık göstermişlerdir. Bu zaviyelerin mensup olduğu tarikatlar ile Yunus Emre'nin mensubu olabileceği düşünülen tarikatlar arasında veya bu tarikatların kolları arasında bir bağ kurulamamıştır. Yunus Emre'nin yaşadığı dönemin zengin tarikat yapısının Eskişehir kent merkezinde kurulan zaviyelere de yansıdığı görülmektedir.

\section{Kaynakça}

Altınok, B. Y. (2017). Yeni vesikalara göre Yunus Emre’nin Ahi Evran, Hacı Bektaşve Şeyh Ede Balı ile ilişkisi, Tavukçu, O. K. (Ed.) Yunus Emre Kitabı, (229-242) içinde Ankara: T.C Aksaray Valiliği İl Kültür ve Turizm Müdürlüğü Kültür Yayınları. Erişim adresi: https://aksaray.ktb.gov.tr/

Altınsapan, E. (1999). Ortaçă̆ga Eskişehir ve çevresinde Türk sanatı. Eskişehir: Anadolu Üniversitesi Yayınları.

Altınsapan, E. ve Parla, C. (2010). Eskişehir zaviye ve türbeleri. Eskişehir: Anadolu Üniversitesi Yayınları.

Azamat, N. (2001). Kadiriyye. İslam ansiklopedisi, 24, 131-136. Erişim adresi: https://islamansiklopedisi.org.tr/

Caca Oğlu Nur El-din (1989). Kırşehir Emiri Caca Oğlu Nur El-din’in 1272 tarihli Arapça-Moğolca vakfiyesi, A. Temir, (Çev.) Ankara: Türk Tarih Kurumu Yayını.

Çatak, A. (2012). Şihabeddin Sühreverdi hayatı eserleri ve tasavvuf anlayışı. Ankara: Gümüşhane Üniversitesi Yayınları. 
Çelik, İ. (2017). Bir Zirve Öyküsü: XIV-XV. asırlarda Anadolu'da tasavvuf ve tarikatlara Hacı Bayram-I Veli merkezli genel bir bakış. 2. Uluslararası Hacı Bayram-ı Veli Sempozyumu Bildiriler Kitabı 1, 03-04 Mayıs 2017, Ankara: Kalem Neşriyat, 21-60. Erişim adresi: https://avesis.atauni.edu.tr/

Doğru, H. (1997). XV. ve XVI. Yüzyıllarda Sivrihisar Nahiyesi. Ankara: T.T. K. Yayınları.

Doğru, H. (2005). XVI. yüzyılda Eskişehir ve Sultanönü Sancağı. Eskişehir: Odunpazarı Belediyesi Yayınları.

Erdoğan, A. (2014). Eskişehir bilgeleri. Ankara: Semih Ofset

Erdoğan, A. (2014). Eskişehir bilgeleri. Ankara: Semih Ofset.

Ertin, G. (1994). Eskişehir kentinde yerleşimin evrimi. Eskişehir: Anadolu Üniversitesi Yayınları.

İhsan. (1934). Eskişehir kitabeleri. Türk Tarih, Arkeologya ve Etnografya Dergisi, (2), 263-268. Erişim adresi: http://isamveri.org/

Kapadokya Mimarlık (Eylül 2007). Eskişehir- Odunpazarı Şeyh Edebali türbesi rölöve-restitüsyon restorasyon raporu. (Yayınlanmamış rapor). Vakıflar Eskişehir Bölge Müdürlügü Arşivi, Eskişehir.

Kılcı, A., Erat, B., Alevsaçar Köse, K., Topkaraoğlu, N., Yiğit N., İncifırat ve Özçelik, A. (2000 öncesi). Eskişehir ili vakıf eski eser ve abideleri, (Yayınlanmamış araştırma). Kütahya Vakıflar Bölge Müdürlügü Arşivi, Kütahya.

Kunter, H. B. (2005). Yunus Emre bilgiler-belgeler. Eskişehir: Eskişehir Valiliği Yayınları.

Manaz, S. (2019). Bizans Dönemi Dorylaion’u ile Anadolu Selçuklu Şehri Sultan Eyü̈̆̈̈/ Sultan Öyüğünün (Eskişehir) fiziki yapıları, (Yayınlanmamış Doktora Tezi). Anadolu Üniversitesi, Eskişehir.

Manaz, S. (2019).[30 Mart 2019 tarihli fotoğraflar]. Kişisel Arşiv. Eskişehir.

Martakçı Nasuh (2014). Beyân-ı menâzil-i sefer-i Irâkeyn, H.G. Yurdaydın (Çev.) Ankara: Türk Tarih Kurumu Yayını.

Özçelik, M. (2010). Bizim Yunus. Ankara: Sistem Ofset. Erişim adresi: Erişim adresi: http://www.yunusemre.net/

Tatc1, M. (2013). Yunus Emre. İslam Ansiklopedisi, (43), 600-606. Erişim adresi: https://islamansiklopedisi.org.tr/

Tatc1, M. (2020). Yunus Emre. Yunus Emre enstitüsü, Türk Dünyası, Ocak-Haziran 2020(2), 3-13. Erişim adresi: https://www.yee.org.tr/tr/yayin/turk-dunyasi-2020-ocak-haziran

Tavukçu, O. K. (2017). Yunus Emre Mektebi: Kurucu Nesil, Tavukçu, O. K. (Ed.) Yunus Emre kitabı, (139-161) içinde. Ankara: T.C Aksaray Valiliği İl Kültür ve Turizm Müdürlüğü Kültür Yayınları. Erişim adresi: https://www.academia.edu/

Topal, M. (2010) Yunus Emre zaviyesi. Eskiyeni Dergisi, 2(15), 70-75. Erişim adresi: http://www.eskisehir.gov.tr/tr/eskiyeni-dergisi.html

Topal, M. (2012) Osmanlı Devleti'nde ahilik ve ahi zaviyeleri. Eskiyeni Dergisi, 3(36), 3-9. Erişim adresi: http://www.eskisehir.gov.tr/tr/eskiyeni-dergisi.html

Topal, M. ve Çolak, K. (2015). Eskişehir zaviyelerine dair tespitler. Alevilik Araştırmaları Dergisi, 5(9), 51-74. Erişim adresi: http://isamveri.org/

Ürkmez, R. K. (2021). 13. yüzyıl tasavvuf hareketleri ve Yunus Emre'nin tasavvufi şahsiyeti. R. Ata (Yay. haz.). Aksaray Üniversitesi Somuncu Baba Tarih ve Kültür Araştırmaları Uygulama ve Araştırma Merkezi Yayın Vefatının 700. Yılında Bizim Yunus Sempozyumu, 26-28 Mayıs 2021, Aksaray: Aksaray Üniversitesi Somuncu Baba Tarih ve Kültür Araştırmaları Uygulama ve Araştırma Merkezi Yayını, 179195. Erişim adresi: https://somuncubaba.aksaray.edu.tr/

Yetim, F. (2005). Yunus Emre'nin kabri ile ilgili görüşler üzerine. Eskişehir Osmangazi Üniversitesi Sosyal Bilimler Dergisi, 6 (1), 171-186. Erişim adresi: https://dergipark.org.tr/ 


\section{Extended Abstract}

\section{Purpose}

The 13th and 14th centuries, in which Yunus Emre lived, cover a time span that includes last period of the Anatolian Seljuks, initial years of the Anatolian Principalities and the foundation Ottoman State.

Anatolia was exposed to the Crusades, Mongol raids and Babai rebellion in those centuries.

In this period of time, not only the religious sects with Anatolian origin established and developed in Anatolia but also religious sects originated elsewhere came into Anatolia and began to spread their ideas and religious order in Anatolian soil.

Therefore, the number of religious sects and zawiyas increased in Anatolia during this period.

The aim of this study is to determine the religious sect that Yunus Emre belonged to and to find out the common features between the religious sect he belonged to and other sects which were established in the city center of Eskisehir.

\section{Design and Methodology}

The study especially focuses on Yunus Emre's education, his works and the Zawiyah established in his name. However, Yunus Emre's education, no mention of 12 Imams in his poems and the change of religious sect with the members of the Zawiyah established in his name in time, made it difficult to determine the religious sect he belonged to. Therefore, it sounds much more plausable to determine the sects he could not be a member of, rather than the sect he belonged to.

Sheikhs and dervishes, who were among the Turks that migrated from Central Asia to Anatolia, laid the foundations of the religious sects in Anatolia. Since Eskişehir was a border city at that time, many zawiyas were established in and around Eskişehir. Today, there are no zawiyes established and active in Eskişehir city center. There are tombs in the places of these zawiyas. It is generally accepted by historians and researchers that there are zawiyas in the places where the tombs are located.

In order to determine the religious sect which Yunus Emre was a member of, all zawiyas established in the city center of Eskişehir during the Seljuk period have been identified.

Then, it is tried to find out the characteristics of the sects that those Zawiyahs belong to and whether they have common features with the sect that Yunus Emre was a member of is investigated.

\section{Findings}

During Yunus Emre's lifetime, Şeyh Şehabeddin Sühreverdi Zawiyah, Abd Allah el Bedevi Zawiyah, Şeyhi Edebali Zawiyah and Ahi Mahmud Zawiyah were established in the Odunpazarı district, which was an Anatolian Seljuk and Ottoman period settlement in the city center of Eskişehir.

Today, there are tombs and mausoleums in place of these zawiyaehs. Sheikh Şehabeddin Sühreverdi Zawiyah: It is located in Odunpazarı District, Paşa Neighbourhood, Kemal Zeytinoğlu Street, number 17. Sheikh Şehabeddin Sühreverdi is the founder of the Sühreverdiyya sect. Zawiyah is popularly known as the Tuesday Zawiyah.

Sheikh Abd Allah el Bedevi Zawiyah: Its location is uncertain. Its district is Karapınar. In the Cacaoğlu Foundation Charter dated 1272, there are many information about the zawiyah of Sheikh Abd Allah al Bedevi. The founder of the Bedeviyye sect is Sayyid Ahmed al-Badawi. 
Sheikh Edebali (b.1206-d.1326) Zawiyah: There is an authority tomb in Odunpazarı. It is generally accepted that Sheikh Edebali is a member of the Vefaiyya sect.

Ahi Mahmud Zawiyah: He is a member of the Ahi organization. In accordance with available data, establishment of Ahi Mahmud Zawiyah is dated back to the Seljuk Period or the foundation years of the Ottoman Empire.

The religious sects that Yunus Emre possibly was belong to are the Nakshi, Halveti, Mevlevi and Kadiri sects. The sect of the dervishes who served in the Yunus Emre Zawiyah, which has been founded around 15th century, does not give us precise information about the subject.

In the Odunpazarı district, which was a popular settlement since the Seljuk and Ottoman periods when Yunus Emre also lived was a very rich and varied religious sect ecology. There were Sheikh Şehabeddin Sühreverdi, Sheikh Abdullh Bedevi, Sheikh Nusreddin, Sheikh Edebali and Ahi Mahmud zawiyas. They all were belonged to different sects. These zawiyas were located within the settlement area which covers a place approximately 2 $\mathrm{km}$. in diameter.

\section{Research Limitations}

In this study, in order to determine the religious sect that Yunus Emre belonged to, his education, his works, the Zawiyahs built in his name and the sects of the Zawiyahs established in the city center of Eskişehir during his lifetime were examined and compared.

\section{Implications (Theoretical, Practial, Social)}

It has not been possible to definitively determine Yunus Emre's sect from the researches carried out to date. It seems that, more detailed results can be obtained with a cooperative effort of an expert team consisting of Turkish Language and Literature, History, Art History and Theology branches in order to determine Yunus Emre's sect. In some sources of the related literature,it is strongly claimed that the religious sect that Yunus Emre was belonged to is certainly and clearly determined. However, this research has shown that it is not possible to precisely determine which sect. Yunus Emre was a member of.

\section{Originality/Value}

This study puts forward the claim that although it is very important to determine which religious sect Yunus Emre belonged to, it is obviously not possible to find out precisely a certain result about the subject. It is not clear who were the mentors of Yunus Emre in the Zawiyahs and what were their religious sects.

The newest record in the Zawiyah established in the name of Yunus Emre goes back to 15th and 16th century. However, it is generally accepted that the foundation of that Zawiyah can be dated to the period of Sultan Orhan or to the period of Sultan Murad I at the latest, since it is stated in the records of the foundation that the zaviyeh is an ancient foundation.

In the study it has been seen that the religious sects which the zawiyas obey were varied in the city center of Eskişehir just like in the time of Yunus Emre and their affiliotions are quite divers.

Araştırmacı Katkısı: Selma MANAZ (\%100). 